\title{
A Study of Soluble-Powdered Natural Dyes
}

\author{
J. S. K. Ngo ${ }^{1}$, W.F. Ong ${ }^{1}$, F. B. Ahmad ${ }^{1}$ and K. B. Bujang ${ }^{1}$ \\ ${ }^{1}$ Deputy Dean (Postgraduate and Research), Faculty of Applied and Creative Arts, \\ Universiti Malaysia Sarawak, Malaysia, jong@faca.unimas.my \\ ${ }^{2}$ Master's Student, Faculty of Applied and Creative Arts, Universiti Malaysia Sarawak, \\ Malaysia, ongwf@hotmail.com \\ ${ }^{3}$ Deputy Dean (Postgraduate and Research), Faculty of Resource Science and Technology, \\ Universiti Malaysia Sarawak, Malaysia, bfasih@frst.unimas.my \\ ${ }^{4}$ Dean, Centre of Graduate Studies, Universiti Malaysia Sarawak, Malaysia, \\ bkopli@pps.unimas.my
}

\begin{abstract}
This paper highlights an on-going study that produces soluble-powdered natural dye extracts from Sebangki barks (Neesia spp., Bomb.; Tristaniopsis spp., Myrt.), Engkerabai Paya leaves (Psychotria viridiflora Zoll. ex. Miq.) and Engkudu roots (Morinda citrifolia L.). These three natural colourants are typically used by the native Iban community in Sarawak to dye silk threads for Pua Kumbu weaving. The two primary objectives of this study are to convert natural dye extracts into soluble powder using solvent extraction and to formulate textile dyeing recipes with good colourfastness and lightfastness using powdered natural dyes extracts. The successful experiments show that distilled water and ethanol can be used as solvents to extract natural dyes from Neesia spp., Bomb.; Tristaniopsis spp., Myrt. barks, Morinda citrifolia L. roots, Psychotria viridiflora Zoll. ex. Miq. leaves. In addition, it is proven that the method of freeze drying is capable of converting liquid dye extracts into soluble powder.
\end{abstract}

Keywords: Solvent Extraction, Soluble-powdered Natural Dyes Extracts, Neesia Spp., Bomb., Tristaniopsis Spp., Myrt., Psychotria Viridiflora Zoll. Ex. Miq., Morinda Citrifolia L., Textile Dyeing

\section{Introduction}

Nowadays, with increased environmental concerns and health-conscious issues, people are beginning to recognise the values of natural products which are believed to be safer and more environmentally friendly. As stated by Al-Amoudi et al. (2009), more eco-friendly dyes are now being developed to replace synthetic dyes which are toxic and hazardous to health.

In recent years, the number of textile practitioners in Malaysia using natural dyes has dwindled significantly due to the labourious process of colour extraction. Chopping, grinding, soaking and boiling are some of the basic steps taken to extract colourants from plants, fruits and vegetables.

\footnotetext{
* Corresponding author. Tel.: (+60) 12 3047782; Fax: (+60) 82581430 E-mail address: jong@ @aca.unimas.my (J.S.K.Ngo)
}

Umbreen et al. (2008) wrote that the textile industry does not extensively embrace the use of natural dyes as there is no standard shade cards and proper application procedures. According to Casselman (1993), time, energy and patience are needed when making natural dyes and it is impossible to produce two dyebaths of the same colour. Consequently, the use of natural dyes in the textile industry has decreased over the years due to the tedious process of colour extraction. In addition, some of the plants, fruits and vegetables used for natural dyeing are seasonal. Thus, in order to reduce the processes involved in dyeing using natural dyes and to have natural dyes readily available for dyeing and printing purposes, they have to be converted into powder form. The shelf life of powdered natural dyes is also expected to be longer than natural dyes in liquid form.

This study uses solvent extraction and freeze 